\title{
Article \\ What Drives Landowners to Resist Selling Their Land? Insights from Ethical Capitalism and Landowners' Perceptions
}

\author{
Ruxandra Malina Petrescu-Mag ${ }^{1}\left(\mathbb{D}\right.$, Hamid Rastegari Kopaei ${ }^{2}$ and Dacinia Crina Petrescu ${ }^{3, *(\mathbb{D})}$ \\ 1 Faculty of Environmental Science and Engineering, Babes-Bolyai University, 30 Fantanele Street, \\ 400294 Cluj-Napoca, Romania; malina.petrescu@ubbcluj.ro \\ 2 Department of Rural Development Management, Faculty of Agriculture, Yasouj University, Yasouj, \\ Square Moalem, Daneshjo Ave., Yasouj 75918-74831, Iran; h.rastegari@stu.yu.ac.ir \\ 3 Faculty of Business, Babes-Bolyai University, 7 Horea Street, 400174 Cluj-Napoca, Romania \\ * Correspondence: crina.petrescu@ubbcluj.ro
}

Citation: Petrescu-Mag, R.M.;

Rastegari Kopaei, H.; Petrescu, D.C. What Drives Landowners to Resist Selling Their Land? Insights from Ethical Capitalism and Landowners' Perceptions. Land 2021, 10, 312. https://doi.org/10.3390/ land10030312

Academic Editor: Tobias Haller

Received: 19 February 2021

Accepted: 15 March 2021

Published: 18 March 2021

Publisher's Note: MDPI stays neutral with regard to jurisdictional claims in published maps and institutional affiliations.

Copyright: (c) 2021 by the authors. Licensee MDPI, Basel, Switzerland. This article is an open access article distributed under the terms and conditions of the Creative Commons Attribution (CC BY) license (https:/ / creativecommons.org/licenses/by/ $4.0 /)$.

\begin{abstract}
Foreign land grabbing is acknowledged as a phenomenon that generates disempowerment and dispossession of local farmers, human rights violations. Previous studies have revealed the lack of ethical benchmarks in foreign large-scale land transactions that raise moral concerns. It is evident that when resources are scarce and people depend on them, the balance between values and interests transforms itself into a dilemma. Within this context, the aims of the paper were to bring to the fore critical reflection on a more ethical perspective of large-scale land acquisitions and to extend the scant information on what factors determine landowners not to sell their land to foreigners to limit land grabbing. This context justifies the need for a critical reflection on a more ethical perspective of large-scale land acquisitions. Therefore, two objectives were set. The first one is to document the role of ethics in large-scale land transactions. Based on the land grabbing literature, authors selected a set of eight land grabbing narratives, most often interrelated and overlapping, that pose ethical considerations. The second objective is to reveal how well a set of variables can predict the "Resistance to sell" the land to foreigners even when an attractive price is offered. As ethics is a social construct, the analysis captured the stakeholders' perspective on land grabbing. Therefore, a questionnaire was applied to a sample of 332 Romanian landowners from twelve randomly selected counties to reveal their perceptions. Partial least squares structural equation modeling (PLS-SEM) was used to observe how well a set of seven variables could predict landowners' "Resistance to sell" their land to foreign buyers. The use of PLS-SEM was justified by the existence of single items and the need to examine many structural model relations. Results showed that the variables with the strongest contribution to the prediction of the dependent variable are the "Probability to join an association for farmers rights defense", the "Importance of the land price offered by the potential foreign buyer", and the "Perceived effect of agricultural land conversion to urban land". Raising awareness on the importance of buyer attributes, increasing people's perception of the negative effect of agricultural land conversion to urban land, or strengthening the state's image as a necessary actor to limit land grabbing will increase landowners' resistance to sell their land to foreigners. Finally, it can be inferred that, within this frame of discussion, ethics should be valued as a means to create economically viable and morally justifiable solutions for foreign large-scale land transactions.
\end{abstract}

Keywords: land grabbing; perceptions; ethics; price; Romania

\section{Introduction}

Land grabbing is one triggering factor of agrarian change that reshaped rural Romania, which led to the restructuring of landscapes and livelihoods with visible environmental consequences and socio-economic implications [1]. There is no official statistical information on the number of foreign investors who own agricultural land, but, according to data from various sources [2], about 30\% of Romania's agricultural land has come into 
foreign investors' possession. Worldwide, land grabbing is triggered by a large number of drivers. Giovannetti and Ticci [3] point to biofuel-related projects that amplified international land acquisitions, showing that biofuel crops account for a share of about $54 \%$ in terms of the total number of deals in Africa. Green pretexts of areas in need of protection have contributed to land dispossession [4-7]. The distribution and accessibility of food are judged as the main drivers towards land $[8,9]$. Not least, developing nations in a rush to attract foreign direct investments increase the number of land grabbers [10,11]. The developed world is not bypassed by illegal land transactions commonly associated with bribes to access land for urban development [12]. Soil fertility, the permissive normative framework for foreign land acquisition, or the affordable land price are named [13,14] among the significant factors that have stimulated land grab in Romania. According to Eurostat [15], Romania has the cheapest arable land, with a hectare costing an average of EUR 1958, whereas the most expensive is in the Netherlands, at about EUR 63,000.

Land grabbing is a controversial concept [16], with no commonly accepted definition. Baker-Smith and Szocs Boruss [17] understand land grabbing as "the control (whether through ownership, lease, concession contracts, quotas, or general power) of larger than locally typical amounts of land by any person or entity (public or private, foreign or domestic) via any means ('legal' or 'illegal') for purposes of speculation, extraction, resource control or commodification at the expense of peasant farmers, agroecology, land stewardship, food sovereignty, and human rights." As can be observed, many scholars [16,17] agree that land grabbing does not necessarily imply that a transaction is illegal or that it is always a harmful process. Hall [18] warns that this concept knows vast differences in the legality, structure, and outcomes of land deals. He emphasizes domestic elites and governments' roles as partners, intermediaries, and beneficiaries of land grabbing. Therefore, a uniform land grab metanarrative is not applicable [19]. Margulis et al. highlight that land grabbing is mainly a control grabbing over resources, as it is "characterized by transnational and domestic corporate investors, governments, and local elites taking control over large quantities of land (and its minerals and water) to produce food, feed, biofuel, and other industrial commodities for the international or domestic markets" [20]. This definition also mentions that land grabbing can be both national and foreign, although foreign land grabbing is the core of this phenomenon. In the case of Romania, the buyers of large land surfaces are mostly foreigners. Land Matrix is an international database that registers land transactions over 200 hectares, and it one of the most complete and reliable data sources for large land transactions. According to Land Matrix, there are only three companies registered in Romania among the top parent companies of land investors in Romania (Maxagro SRL, ADS, and Lord Energy SRL), all the others being foreign, mostly from the EU [21]. These three companies cover together less than $6 \%$ of the total deals under contracts in Romania (over 200 ha). For this reason, the present study focuses on foreign land grabbing.

Local farmers affected by land grabbing have been widely portrayed as victims [22,23]. It is argued that foreign land grabbing that is transnational in nature enriches foreign investors [24] and generates disempowerment and dispossession of local farmers [25], arriving at the violation of human rights [26]. Land grabbing leads to the transfer of control over property and resources located on extended territories from the local level to outsiders within transactions dominated by an asymmetry of power. Thus, it is considered an economic, cultural, and ecological threat to rural communities [27]. It was estimated that as a direct result of land grabbing, 200-300 million people globally were at risk of greater food insecurity [28]. From an economic perspective, land grabbing might cause income loss of over 12 million people globally and that it had serious implications for food security, poverty levels, and urbanization [28]. In Romania, low land price, good soil quality, rural desertification, lack of adequate loan opportunities for local rural inhabitants, liberalization of land market to other EU member states, and corruption enhanced people vulnerability in front of foreign buying proposals for land and lead to the transfer of between $20 \%$ and $50 \%$ of the land to foreign property in some counties [13]. This evidence emerging from the existing land grabbing literature justifies the need for a critical reflection on a more 
ethical perspective of large-scale land acquisitions. Margulis [29] explained that large-scale land acquisitions are seen as unethical when they undermine sustainable development principles and when they result in constraints that force the poor to work for the wealthy. The present contribution considers that ethics should be valued as an integral part of day-to-day choices and decisions in land management [30] and that it should play its role, not as a guest but as a guide [31] regarding land grabbing — a statement further argued in detail in Section 2.

Within this frame of discussion, the paper aims to bring to the fore critical reflection on a more ethical perspective of large-scale land acquisitions and extend the scant information on what factors determine landowners not to sell their land to foreigners to limit land grabbing. Therefore, two objectives were set: (i) the first one is to document the role of ethics in large-scale land transactions; (ii) the second objective is to reveal how well a set of variables can predict Romanian landowners' resistance to sell the land to foreigners even if an attractive price is offered.

Even if the present contribution embeds a place-based analysis that reveals the local environment, it also responds to a fast-evolving European phenomenon. Like other studies, the present one discusses the land grabbing phenomenon in the light of the current social context $[32,33]$ and the trends of rural development in European societies [34]. Nevertheless, the discussion on foreign large-scale land acquisitions was brought to the sphere of normative ethics. Thus, this paper adds to the existing land grabbing literature by revealing the effect of seven variables on landowners' resistance to sell their land to foreign buyers to limit land grabbing. Although the current research on "global land grabbing" [9,35-38] has enriched the understanding of the roles of various actors and factors involved in land deals, no study has identified, so far, the factors that can influence the landowners' decision to refuse to sell the land even when a good price is offered. Thus, while other studies investigated the people's reasons for persistent landownership in the rural-urban fringe [39] or land attachment in general [40-42], this is the first attempt to reveal factors contributing to Romanian landowners' resistance to sell within the foreign land grabbing context.

\section{Ethical Capitalism and the Need for Ethics in Large-Scale Land Transactions}

Within the land grabbing equation, grabbers perceive land value much higher than the price paid for it, which is the underlying reason for land acquisitions' magnitude. As a result, in practice, foreign land investors act competitively to meet their unlimited wants with their limited means [43], put their financial benefits first and offer as little as possible to other stakeholders, like farmers and other landowners. This approach ignores the reality of value creation as a collective process and, because, most often, large-scale land transactions take place within the capitalism framework, it can be inferred that one of the greatest weaknesses of capitalism is that it confuses the price with value [44]. In the case of land, these specific conditions and factors influence the land's value, at a certain level. Place attachment, national security, and traditional preservation as creators of land value can be named here.

Lefebvre and Nicholson-Smith [45] observe that "capitalism has taken possession of the land", meaning that land is most often seen only as a concept of political economy in a worldwide context where $40 \%$ of the economic activities of many capitalist countries are connected to land [46]. Yes, the land is capital and commodity, but, as per Polany [47], it is a fictitious commodity that fulfills a social necessity. If the land is treated only as a commodity for sale on the market, our social world will be endangered rather than protecting rights related to it [48]. David Bollier [49] says the land is "embedded in social relationships and subject to the moral consideration." That is why it is time to rethink the role of land in economics and other sciences [50].

The concept "ethical capitalism" refers to acting in business [51] and because largescale land transactions are a flourishing business, the discussion about "ethical capitalism" in this context can contribute to overcoming some of the negative land grabbing consequences. Capitalism is neutral; it is neither ethical nor unethical [52]. It is about us, 
those who practice it, who can act either morally or immorally. Ethics is about people. Ethical initiatives are often initiated by civil society, and this kind of private value-oriented action influencing market behavior can be called ethical capitalism [24]. Moreover, ethical capitalism is about corporations' responses to ethical concerns that the legal framework does not address [51].

Ethical capitalism must lead to changed behaviors [53], but we must know these changing behaviors before changing them. Consequently, the investigation of people's perception of land grabbing is relevant because justice, in general, is constructed and negotiated through social interaction, and it is based on the compatibility of supporting values [54]. As argued by Asiama et al. [43], owners' views (perceptions, in our case) on large-scale land transactions should be studied because this approach will help determine the land value that people will agree with. From a practical perspective, knowledge creation based on the investigation of the gravity of the land grabbing phenomenon, its impact on jobs, the environment, and food security can contribute to future land law amendments.

Zooming in on land rush literature, it is evident that land grabbing cannot be judged only in black or white, as some see land grabs as a significant threat to rural communities' livelihoods, while others consider these transactions as an economic opportunity. Even if intermediate views still exist (see, for example, Borras and Franco [55]), most studies tend to consider mainly the imputations of land grabbing, which conjure up a future of resource scarcity, environmental depletion, food insecurity, or infringement of local community rights. Practically, this perspective places the land grabbing debate on the "us against them" axis (where "us" represents the local farmers and "them", foreign investors) along with the emphasis of land grabbing negative consequences that outweigh the benefits. Idealistically, all participants in a land transaction would act based on ethical values. Practically, the lack of ethical benchmarks constructed a rich vein of research that reports land grabbing narratives that raise ethical concerns. Unfortunately, when resources are scarce and people rely so much on them, the balance between values and interests transforms into a real dilemma [24].

Based on the land grabbing literature, authors distinguished a set of eight narratives, most often interrelated and overlapping, that pose ethical considerations linked to land transactions. These are "Agricultural land loss to urban sprawl-land grabbing" narrative [56,57]; "Environment depletion-land grabbing" narrative [58-60]; "Weak solidarity among farmers" narrative [61,62]; "Questioning of business ethics-land grabbing" narrative [35]; "Food insecurity-land grabbing" narrative [9,63,64]; "Lack of collaborative governance-land grabbing" narrative $[14,65,66]$; "Future overall gravity-land grabbing narrative" [14,67-69]; and "Xenophobia-land grabbing" narrative [70,71].

According to Damen [24], the introduction of ethical dilemmas raises, in its turn, a policy dilemma. One big question in land management decisions is how to balance economic interests and ethical values. Literature offers several answers. There are authors [72] who suggest that corporate social responsibility and a model code of conduct, promoted by international organizations, can be a solution for the conflicts arising from agrarian transformations driven by land grabbing. How the principles of such codes might work in practice is difficult to envisage. Other authors highlight problems, doubts, and concerns regarding codes of conduct and warn that they may, in fact, facilitate land grabbing because they do not address the roots of land grabbing [55]. In their opinion, the solution is a new distribution of political forces (from international to local levels) that follows a human rights-based approach [55]. Practically, international organizations (e.g., the Food and Agriculture Organization, the International Fund for Agricultural Development) cannot significantly contribute to the fight against land grabbing' negative consequences, as it is a phenomenon linked to property law and national policies [24]. Factors, such as different interpretations of the same regulatory instrument by the actors involved, the existence of legally pluralistic contexts, or the multi-facets of conflicts that cannot be solved with a single instrument alone, are blamed [73] for the failure of the international initiatives. Let us turn the attention to domestic law. It is acknowledged that there is wide variability in 
the legal underpinnings of customary rights and legislated processes for large-scale land acquisition [74], and legislative gaps often contribute to shaping the opportunities and risks faced by landowners.

Within the land grabbing context, normative ethics contribute to the debate on specific narratives that encompass social equity, human capabilities, or environment protection. In this analysis, ethics is valued as a social construct built by negotiating interpretations of morally desirable situations and behaviors accepted in a particular society (Romanian society, in the present case) at a specific historical moment [75]. This definition of ethics needs some more clarification. Ethics may be context-dependent [76,77], and even when individuals recognize some standard ethical norms, they can interpret and apply them differently under their values and life experiences [78]. To put the point a little bit more empirically, how can landowners make ethical decisions about selling their land? Large-scale agribusinesses are often portrayed as culpable for environmental degradation following their agricultural activity [79], and thus they infringe one of Bawden's [80] ethical canons, namely, "the principle of non-maleficence". Liao et al. [81] concluded that because of land-cover change brought by large foreign farmland transactions, amounts of carbon emissions could be emitted when transacted land is located in high carbon value forests. A rich literature highlights that land transactions accelerated deforestation [82-84]. Cardoso and James [85] said that very little research exists concerning farmers' or landowners' ethical frameworks and the extent to which ethics affects their decisions. Several models exist explaining ethical decision-making [85-87]. If we follow Jones's [87] definition of ethical decision, as "a decision that is both legal and morally acceptable to the larger community ... an unethical decision is either illegal or morally unacceptable to the larger community", one could say that as long as the land grabbing negatively impact on environmental balance, displacement of small farmers, or food security, the ethical approach means the limitation of the land grabbing phenomenon. The temporary freeze on investments involving large-scale land acquisitions that are already in place (e.g., Mozambique and Cambodia) or information campaigns of local communities that empower them to give or refuse consent to a project, guarantees of project transparency so that investors can be held accountable both to affected communities and to the government, are some of the ethical solutions.

Ethics, seen as a social construct, requires that the discussion includes the stakeholders' perspectives (landowners in the present study). We asked how landowners can make "right" decisions about land transactions in a world marked by the chaos of values. Meijboom and Stafleu [88] argue that farmers have moral beliefs and values, and thus they can contribute to the public debate on relevant agricultural issues, from animal welfare, sustainable food production, to environmental protection. That is why the focus of this study is placed on landowners (who may be farmers or not) considered stakeholders in land transactions. Practically, stakeholder analysis generates knowledge about stakeholders' actions that helps us understand their behavior, intentions, and interests. According to Varvasovszky and Brugha [89], stakeholder analysis assesses the influence of these interests on decision making or implementation processes. Landowners' perceptions are worthy of investigation as any change or maintenance of the status quo in land transactions is possible only with their involvement which depends on their perceptions, knowledge, and needs [75].

\section{Materials and Methods}

\subsection{Study Area}

Romania (Figure 1) is a member of the European Union, located in the southeast of Central Europe. It has an area of $238,391 \mathrm{~km}^{2}$ that represents $4.8 \%$ of the territory of Europe and $5.4 \%$ of the area of the European Union [90], respectively. The Romanian rural area covers $207,522 \mathrm{~km}^{2}$, representing $87.1 \%$ of the country's surface, and concentrates 9.2 million inhabitants ( $46.0 \%$ of the total population) [90,91]. The share of the agricultural sector in the gross domestic product (GDP) in 2019 was 4.1\%, knowing a downward trend 
(for example, in 2011, its contribution to the GDP was 6.25\%) [92]. Romania ranks 49th in the Human Development Index [93].

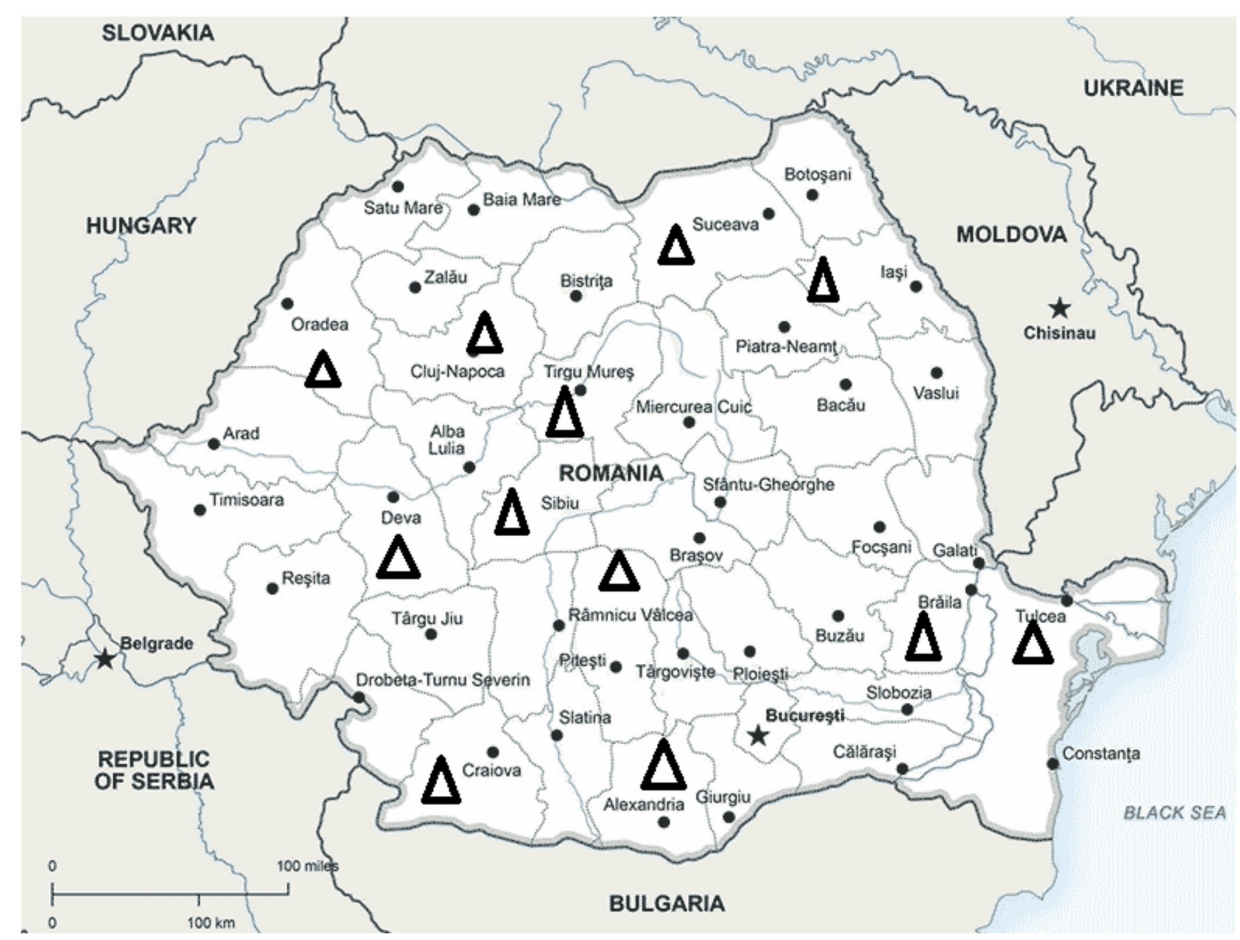

Figure 1. Study area and location of interviewed landowners on the Romania map (black triangles indicate the twelve counties where the interviews were carried on).

\subsection{Data Collection}

Data were collected as follows. Twelve counties (marked in Figure 1) were selected at random, and three cities/villages were randomly selected in each county. Randomness was ensured as follows. The authors created a list with the 41 counties of Romania plus de capital and numbered them. A list with 12 random numbers was generated in Excel and the counties with those numbers were selected for the survey. The same procedure was followed to select the three cities/villages in each of the twelve counties. The lists with counties, cities, and villages are available online. In each city/village, a list with streets was generated using the information available online and one street was randomly selected. Interviewers created a list of the supermarkets, pharmacies, and markets that functioned on that street and one of them was randomly selected. If no shop existed on the selected street, a new street was picked at random. An interview was requested for each fourth person who came out of the selected shop. Between six and ten interviews were carried on in each city/village on a person who was over 18 years old and owned land. The acceptance to respond rate with complete answers was $21 \%$. Participation in the survey was voluntary, and respondents were informed about the nature of the research.

As a consequence of the successive agricultural reforms aimed at land property restitution, urban citizens represent a significant percentage of landowners. Consequently, both urban and rural localities were considered, and landowners were the target group in this research regardless of their quality of being or not farmers. The final sample included 332 Romanian citizens.

\subsection{Investigated Variables}

The economic structure of agriculture, the political instability, and land market volatility, for example, show that the landowners have limited choices in their land management decisions. The perceived economic pressure is practically directly correlated with landowners participating in ethically questionable land transactions [94,95]. At the outset, it was 
assumed that Romanian landowners have often found themselves in an ethical dilemma to meet what seem to be conflicting needs and values. More precisely, these can be the perception of personal well-being through the money received in large scale land transactions vs. the impact of landowner's selling decision on the environment, food security, community welfare (see also $[88,95,96]$ for the argumentation of the existing farmers' moral beliefs and values). The present study questioned the relationship between a set of seven variables and landowners' decisions of not selling the land to foreign investors. "Not sell to foreign investors, even if they offer you a good price" (briefly named "Resistance to Sell") was set as the dependent variable. Often, foreign investors offer higher prices than domestic ones, so the higher price was included in the scenario. The rest of the selected variables (Table 1) were independent variables. The selection of the variables relies on Messerli et al.'s [97] system knowledge. Based on an extensive literature review, Messerli et al. [97] tried to understand large-scale land acquisition from the systems perspective that asks questions about the land grabbing's overall scale and its main characteristics. Landowners' perceptions of a specific phenomenon, like land grabbing, depend on the existing knowledge about the investigated topic [98]. Consequently, considering the primary actors' perceptions-Romanian landowners-of the land grabbing phenomenon is critical in affecting land use behavior $[99,100]$. The variables were further associated with the eight land grabbing ethical narratives (detailed in Section 2).

Table 1. Investigated variables (the short name used for each variable in the partial least squares structural equation modeling (PLS-SEM) analysis is written between brackets in the first column).

\begin{tabular}{|c|c|c|c|}
\hline Investigated Variables & $\begin{array}{l}\text { Association with the } \\
\text { Identified Land Grabbing } \\
\text { Narratives }\end{array}$ & $\begin{array}{c}\text { Questionnaire } \\
\text { Question/Statement }\end{array}$ & Answer Options \\
\hline $\begin{array}{l}\text { Perceived gravity of foreign land } \\
\text { grabbing over the next } 10 \text { years } \\
\text { (independent variable) (LG gravity) }\end{array}$ & $\begin{array}{l}\text { "Future overall gravity-land } \\
\text { grabbing" narrative }\end{array}$ & $\begin{array}{l}\text { How do you assess the gravity } \\
\text { of foreign land grabbing in the } \\
\text { next } 10 \text { years in Romania? }\end{array}$ & $\begin{array}{l}1=\text { Not serious at all to } \\
5=\text { Very high gravity }\end{array}$ \\
\hline $\begin{array}{l}\text { Perceived effect of foreign land } \\
\text { grabbing on the natural environment } \\
\text { (independent variable) (LG impact on } \\
\text { the nat environment) }\end{array}$ & $\begin{array}{l}\text { "Environment depletion-land } \\
\text { grabbing" narrative }\end{array}$ & $\begin{array}{l}\text { The purchase of large } \\
\text { agricultural land by foreigners } \\
\text { will have negative } \\
\text { consequences on the state of } \\
\text { the natural environment } \\
\text { (reverse coding). }\end{array}$ & $\begin{array}{l}1=\text { Total disagreement } \\
\text { to } 5=\text { Total agreement }\end{array}$ \\
\hline $\begin{array}{l}\text { Perceived effect of agricultural land } \\
\text { conversion to urban land } \\
\text { (independent variable) (Effect of land } \\
\text { conversion agric to urban) }\end{array}$ & $\begin{array}{l}\text { "Agricultural land loss to } \\
\text { urban sprawl-land grabbing" } \\
\text { narrative; "Food } \\
\text { insecurity-land grabbing" } \\
\text { narrative }\end{array}$ & $\begin{array}{l}\text { It is good that cities expand } \\
\text { and build on the agricultural } \\
\text { land? }\end{array}$ & $\begin{array}{l}1=\text { Total agreement to } \\
5=\text { Total disagreement }\end{array}$ \\
\hline $\begin{array}{l}\text { Influence of the land price offered by } \\
\text { the potential foreign buyer } \\
\text { (independent variable) (Influence of } \\
\text { price received) }\end{array}$ & - & $\begin{array}{l}\text { How much does the price } \\
\text { influence your decision to sell } \\
\text { your land to foreign investors? } \\
\text { (variable not linked to any } \\
\text { narrative) }\end{array}$ & $\begin{array}{l}1=\text { Very little to } \\
5=\text { Very much }\end{array}$ \\
\hline $\begin{array}{l}\text { Perceived need for state intervention } \\
\text { to limit foreign land grabbing } \\
\text { phenomenon (independent variable) } \\
\text { (Need for state intervention) }\end{array}$ & $\begin{array}{l}\text { "Lack of collaborative } \\
\text { governance-land grabbing" } \\
\text { narrative }\end{array}$ & $\begin{array}{l}\text { How big is the need for the } \\
\text { Romanian state to take } \\
\text { measures to limit the } \\
\text { phenomenon of land } \\
\text { grabbing? }\end{array}$ & $\begin{array}{l}1=\text { Very small to } \\
5=\text { Very high }\end{array}$ \\
\hline
\end{tabular}


Table 1. Cont.

\begin{tabular}{|c|c|c|c|}
\hline Investigated Variables & $\begin{array}{l}\text { Association with the } \\
\text { Identified Land Grabbing } \\
\text { Narratives }\end{array}$ & $\begin{array}{c}\text { Questionnaire } \\
\text { Question/Statement }\end{array}$ & Answer Options \\
\hline $\begin{array}{l}\text { Importance of buyer attributes } \\
\text { (independent variables, computed as } \\
\text { a mean of three items: a. to c.) } \\
\text { (Importance of buyer attributes) }\end{array}$ & $\begin{array}{l}\text { "Questioning of business } \\
\text { ethics-land grabbing" } \\
\text { narrative; "Food } \\
\text { insecurity-land grabbing" } \\
\text { narrative; "Environment } \\
\text { depletion-land grabbing" } \\
\text { narrative } \\
\text { "Xenophobia-land grabbing" } \\
\text { narrative }\end{array}$ & $\begin{array}{l}\text { Show how important the } \\
\text { following aspects related to } \\
\text { the buyer are for you when } \\
\text { you decide to sell your land: } \\
\text { a. Future land destination } \\
\text { b. Nationality: if the buyer is } \\
\text { Romanian or a foreigner } \\
\text { c. Age (demographic variable } \\
\text { not linked to any narrative) }\end{array}$ & $\begin{array}{l}1=\text { Not at all } \\
\text { important to } 5=\text { Very } \\
\text { high importance }\end{array}$ \\
\hline $\begin{array}{l}\text { Probability to join an association for } \\
\text { farmers rights defense to limit the } \\
\text { land grabbing phenomenon } \\
\text { (Probability to join a farmers' rights } \\
\text { association) (independent variable) }\end{array}$ & $\begin{array}{l}\text { "Weak solidarity among } \\
\text { farmers" narrative }\end{array}$ & $\begin{array}{l}\text { What is the probability that } \\
\text { you join an association that } \\
\text { defends farmers' rights to } \\
\text { limit the phenomenon of land } \\
\text { grabbing? }\end{array}$ & $\begin{array}{l}1=\text { Very low } \\
\text { probability to } 5=\text { Very } \\
\text { high probability } \\
\text { (reverse coded here } \\
\text { compared to how it } \\
\text { was presented to } \\
\text { respondents) }\end{array}$ \\
\hline $\begin{array}{l}\text { Probability of not selling the land to } \\
\text { foreign investors, even if they offer a } \\
\text { good price, to limit the land grabbing } \\
\text { phenomenon (dependent variable) } \\
\text { (Resistance to sell) }\end{array}$ & $\begin{array}{l}\text { "Xenophobia-land grabbing" } \\
\text { narrative }\end{array}$ & $\begin{array}{l}\text { What is the probability that } \\
\text { you do not sell your land to } \\
\text { foreign investors, even if they } \\
\text { offer you a good price, to limit } \\
\text { the phenomenon of land } \\
\text { grabbing? }\end{array}$ & $\begin{array}{l}1=\text { Very low } \\
\text { probability to } 5=\text { Very } \\
\text { high probability } \\
\text { (reverse coded here } \\
\text { compared to how it } \\
\text { was presented to } \\
\text { respondents) }\end{array}$ \\
\hline
\end{tabular}

\subsection{Data Analyses}

Univariate analyses were made using Excel and SPSS. To discover the causal relationships between the construct, partial least squares structural equation modeling (PLS-SEM) was run. Structural equations model (SEM) based on partial least squares (PLS) were used through SmartPLS software (3.2.8). This software has a high ability to discover the causal relationships of complex models [101]. PLS-SEM was preferred because it depends less on the assumed normal distribution and, consequently, it has higher estimation accuracy, it is well-fitted in a construct with a single measurement, and it is acceptable for most research predictions [102]. Another strength of the PLS method is that a construct with only one indicator does not create a problem in the PLS method computation process [103]. Further, this software has a special ability in calculating formative and reflective measurements [101]. In other words, the software facilitates and confirms relationships, based on the relationships between research variables indicated by the researcher. In the present study, only the formative measurement was used. The "Resistance to sell" is the main construct of the model. There are direct relationships between the main construct and exogenous constructs such as the "Need for state intervention", the "Importance of buyer attributes", the "Perceived effect of agricultural land conversion to urban land", and the "Perceived effect of foreign land grabbing on the natural environment". There are also indirect relationships such as between the main construct and the "Perceived gravity of foreign land grabbing over the next 10 years" through the "Influence of the land price offered by the potential foreign buyer". Several methods can be used to draw a model and determine direct or indirect paths, such as theory, logic, previous research, qualitative research, or researcher judgment [101]. In this paper, we used previous research, logic, and researcher judgment.

Furthermore, 500 samples were used for bootstrapping method. Then, to ensure the correctness of the analysis with 300 samples, the bootstrapping method was performed again, which showed that the path coefficients and significant levels of the model are 
not different from each other and are valid for further interpretation of the model. This property has important implications for testing the significances of the model coefficients.

\section{Results}

The sample characteristics are presented in Table 2. Descriptive statistical tests were run in SPSS. The demographic profile of interviewed persons was described by gender, age, education, residence area (rural, and urban), and income (Table 2).

As can be seen in Table 3, the "Gravity of foreign land grabbing gravity over the next 10 years" and the "Need for state intervention to limit foreign land grabbing phenomenon" had the highest mean. This result showed that according to the Romanians, the government has a very high responsibility in limiting land grabbing. Moreover, Romanians believed that the phenomenon of land grabbing would seriously intensify in the next 10 years.

Table 2. Sample characteristics.

\begin{tabular}{ccc}
\hline Variables & Categories & Percent \\
\hline \multirow{2}{*}{ Gender } & Female & 42.5 \\
& Male & 57.5 \\
\hline \multirow{2}{*}{ Residence } & Rural & 55.7 \\
& Urban & 44.3 \\
\hline \multirow{2}{*}{ Family income } & Max 1000 lei (200 Euro) $/$ month & 2.4 \\
& 1001-2000 lei (201-400 Euro/month $/$ month & 19.6 \\
& 2001-4000 lei (401-800 Euro) $/$ month & 37.3 \\
& 4001-6000 lei (801-1200 Euro)/month & 25.0 \\
Education level & Over 6001 lei (1201 Euro)/month & 15.7 \\
\hline Age & 8 years (Primary education) & 6.3 \\
& 12 years (Secondary education) & 50.6 \\
\hline & Higher education & 43.1 \\
\hline
\end{tabular}

Table 3. Descriptive statistics of investigated variables.

\begin{tabular}{|c|c|c|c|}
\hline Variables & $\mathbf{N}$ & Mean & Std. Deviation \\
\hline $\begin{array}{l}\text { Perceived gravity of foreign land grabbing gravity } \\
\text { over the next } 10 \text { years }(1=\text { Not serious at all; } \\
5=\text { Very high gravity) }\end{array}$ & 332 & 4.25 & 0.92 \\
\hline $\begin{array}{l}\text { Perceived effect of foreign land grabbing on the } \\
\text { natural environment (negative effect was tested; } \\
1 \text { = Total disagreement; } 5 \text { = Total agreement) }\end{array}$ & 332 & 3.10 & 1.04 \\
\hline $\begin{array}{l}\text { Perceived effect of agricultural land conversion to } \\
\text { urban land (positive effect was tested; } 1=\text { Total } \\
\text { agreement; } 5 \text { = Total disagreement) }\end{array}$ & 332 & 3.49 & 0.95 \\
\hline $\begin{array}{l}\text { Influence of the land price offered by the potential } \\
\text { foreign buyer ( } 1 \text { = Very little; } 5=\text { Very much) }\end{array}$ & 332 & 3.88 & 1.28 \\
\hline $\begin{array}{l}\text { Perceived need for state intervention to limit } \\
\text { foreign land grabbing phenomenon }(1=\text { Very small; } \\
5 \text { = Very high) }\end{array}$ & 332 & 4.25 & 0.91 \\
\hline $\begin{array}{l}\text { Importance of buyer attributes * }(1=\text { Not at all } \\
\text { important; } 5=\text { Very high importance })\end{array}$ & 332 & 2.92 & 0.78 \\
\hline $\begin{array}{l}\text { Probability of joining an association that defends } \\
\text { farmers' rights to limit the land grabbing } \\
\text { phenomenon ( } 1=\text { Very low probability; } 5=\text { Very } \\
\text { high probability) }\end{array}$ & 332 & 2.70 & 1.22 \\
\hline
\end{tabular}


Table 3. Cont.

\begin{tabular}{llcc}
\hline \multicolumn{1}{c}{ Variables } & N & Mean & Std. Deviation \\
\hline $\begin{array}{l}\text { Probability of not selling the land to foreign } \\
\text { investors, even if they offer a good price, to limit } \\
\text { the land grabbing phenomenon }(1 \text { = Very low } \\
\text { probability; } 5 \text { = Very high probability) }\end{array}$ & 332 & 3.01 & 1.192 \\
* This variable was computed as average score of the items indicated in Table 3.
\end{tabular}

\subsection{Measurement Model}

To obtain valid results from the structural model of the research, first, the optimal conditions of the structural model should be provided using the measurement model. Figure 2 contains seven independent variables and one dependent variable. Figure 2 shows that out of eight variables, six variables were measured using an indicator "Perceived gravity of foreign land grabbing", "Influence of price received", "Perceived need for state intervention to limit foreign land grabbing", "Probability to join an association for farmers rights defense", "Perceived effect of foreign land grabbing on the natural environment", "Perceived effect of agricultural land conversion to urban land", and "Resistance to sell"), and one variable was measured using three indicators ("Importance of buyer attributes"). The model constructs were all measured using one indicator, except for the importance of buyer attributes. For this purpose, the model needed to assess the validity. As shown in Figure 2, the "Importance of buyer attributes" construct was a formative construct. Its convergent validity, multicollinearity between indicators, and outer weight were measured. Convergent validity $(\beta=0.748)$ and multicollinearity (ranged 1 to 1.113 ) were confirmed. Outer weights are shown in Table 4, and all of them are significant [101].

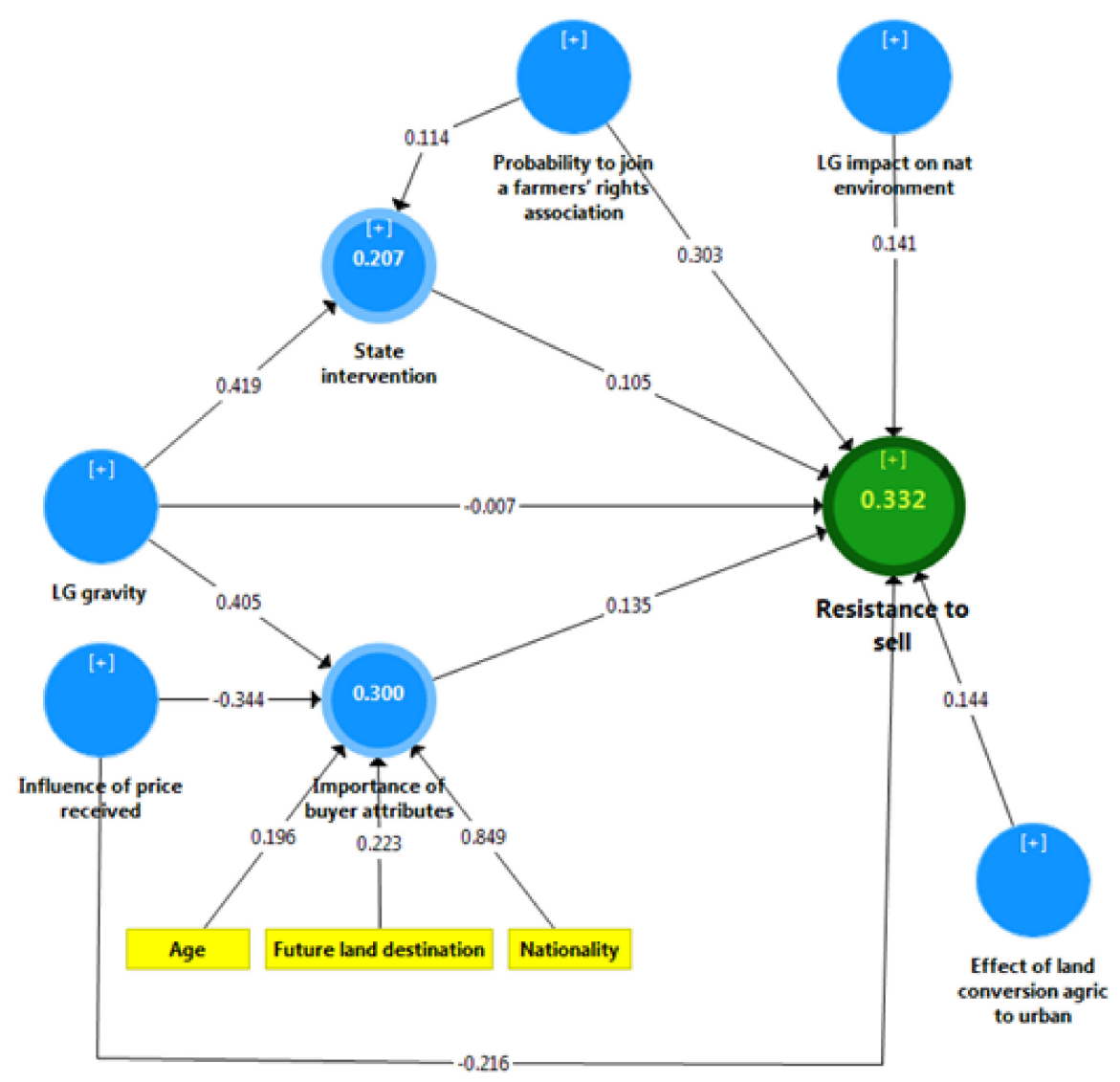

Figure 2. Measurement model designed to predict landowners' "Resistance to sell”. 
Table 4. Measurement formative construct.

\begin{tabular}{ccccc}
\hline $\begin{array}{c}\text { Formative } \\
\text { Construct }\end{array}$ & $\begin{array}{c}\text { Formative } \\
\text { Indicators }\end{array}$ & $\begin{array}{c}\text { Outer Weights } \\
\text { (Outer Loading) }\end{array}$ & t-Value & $\boldsymbol{p}$-Value \\
\hline \multirow{2}{*}{$\begin{array}{c}\text { Importance of buyer } \\
\text { attributes }\end{array}$} & Age & 0.196 & 2.267 & 0.024 \\
& Future land destination & 0.223 & 2.501 & 0.013 \\
& Nationality & 0.849 & 14.456 & 0.000 \\
\hline
\end{tabular}

The general model was drawn after determining the suitability of the constructs. According to the results, Standardized Root Mean Square Residual (SRMR, which is defined as the difference between the observed correlation and the model implied correlation matrix and it is an absolute measure of model fit) was equal to 0.066 , which indicated a good fit model of the research model [101].

\subsection{Structural Model of Landowners' Resistance to Sell}

The results of the research model were presented in Figures 2 and 3. Figure 2 showed the path coefficients between constructs, the outer weights of the indicators of the formative construct, and the $\mathrm{R}^{2}$ of the dependent construct.

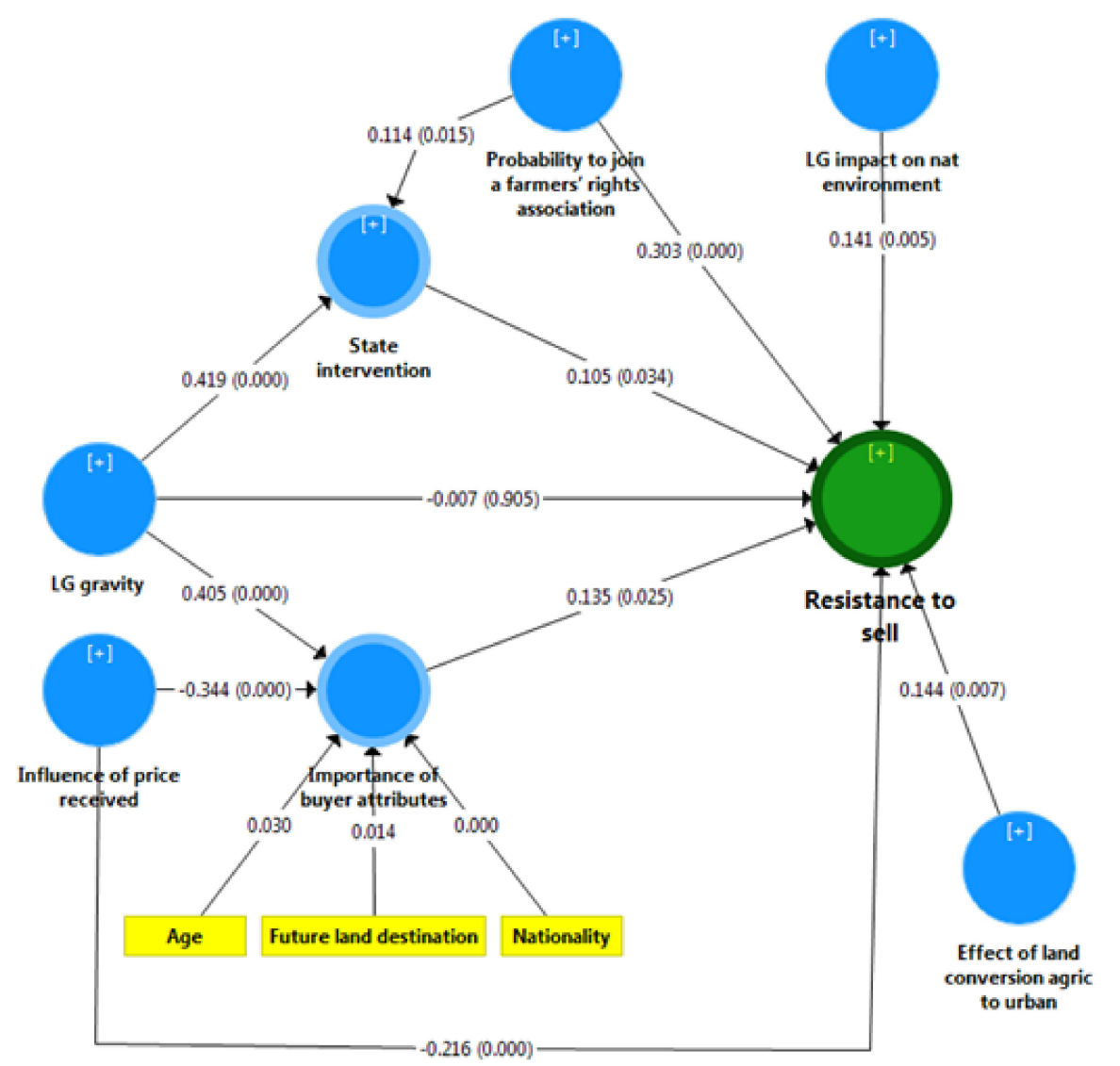

Figure 3. Path coefficients and $p$-values (between brackets) in the structural model designed to predict landowners' "Resistance to sell”.

Figure 3 showed the Path coefficients and the level of significance of the paths. The significance of paths was obtained by bootstrapping. The highest level of significance and coefficient path belonged to the path of "Perceived gravity of foreign land grabbing" to "Perceived need for state intervention to limit land grabbing" and the lowest coefficient path and level of significance belonged to the path of "Perceived need for state intervention to limit land grabbing" to "Resistance to sell". 
Table 5 showed the total effect, direct effect, and indirect effect of constructs. According to Table 5, the effect of "Perceived effect of agricultural land conversion to urban land" had a direct and significant positive effect on resistance to sell $(\beta=0.144$, sig. $=0.008)$. The "Importance of buyer attributes" had a positive and direct effect on resistance to sell $(\beta=0.135$, sig. $=0.028)$.

Table 5. Total effects, direct effects, and indirect effects of the constructs.

\begin{tabular}{|c|c|c|c|c|}
\hline $\begin{array}{l}\text { Path } \\
\text { From } \rightarrow \text { To }\end{array}$ & Effect Type & Coefficients & T Statistics & $p$-Values \\
\hline "Effect of land conversion agric to urban" $\rightarrow$ "Resistance to sell" & DIR & 0.144 & 2.67 & 0.008 \\
\hline "Importance of buyer attributes" $\rightarrow$ "Resistance to sell" & DIR & 0.135 & 2.204 & 0.028 \\
\hline $\begin{array}{l}\text { "Influence of price received" } \rightarrow \text { "Importance of buyer } \\
\text { attributes" }\end{array}$ & DIR & -0.344 & 7.274 & 0.000 \\
\hline "Influence of price received" $\rightarrow$ "Resistance to sell" & DIR & -0.216 & 3.503 & 0.001 \\
\hline $\begin{array}{l}\text { "Influence of price received" } \rightarrow \text { "Importance of buyer attributes" } \\
\rightarrow \text { "Resistance to sell" }\end{array}$ & IND & -0.046 & 2.036 & 0.042 \\
\hline "Influence of price received" $\rightarrow$ "Resistance to sell" & TOT & -0.263 & 4.472 & 0.000 \\
\hline "LG gravity" $\rightarrow$ "Importance of buyer attributes" & DIR & 0.405 & 7.354 & 0.000 \\
\hline "LG gravity" $\rightarrow$ "Resistance to sell" & DIR & -0.007 & 0.119 & 0.906 \\
\hline "LG gravity" $\rightarrow$ "Need for state intervention" & DIR & 0.419 & 7.393 & 0.000 \\
\hline $\begin{array}{l}\text { "LG gravity" } \rightarrow \text { "Importance of buyer attributes" } \rightarrow \\
\text { “Resistance to sell” }\end{array}$ & IND & 0.055 & 2.155 & 0.032 \\
\hline $\begin{array}{l}\text { "LG gravity" } \rightarrow \text { "Need for state intervention" } \rightarrow \text { "Resistance to } \\
\text { sell" }\end{array}$ & IND & 0.044 & 1.890 & 0.059 \\
\hline "LG gravity" $\rightarrow$ "Resistance to sell" & TOT & 0.092 & 1.819 & 0.069 \\
\hline "LG impact on the nat environment" $\rightarrow$ "Resistance to sell" & DIR & 0.141 & 2.754 & 0.006 \\
\hline $\begin{array}{l}\text { "Probability to join a farmers' rights association" } \rightarrow \text { "Resistance } \\
\text { to sell" }\end{array}$ & DIR & 0.303 & 5.847 & 0.000 \\
\hline $\begin{array}{l}\text { Probability to join a farmers' rights association" } \rightarrow \text { "Need for } \\
\text { state intervention" }\end{array}$ & DIR & 0.114 & 2.428 & 0.016 \\
\hline $\begin{array}{l}\text { "Probability to join a farmers' rights association" } \rightarrow \text { "Need for } \\
\text { state intervention" } \rightarrow \text { "Resistance to sell" }\end{array}$ & IND & 0.012 & 1.338 & 0.181 \\
\hline $\begin{array}{l}\text { "Probability to join a farmers' rights association" } \rightarrow \text { "Resistance } \\
\text { to sell" }\end{array}$ & TOT & 0.315 & 6.117 & 0.000 \\
\hline "Need for state intervention" $\rightarrow$ "Resistance to sell" & DIR & 0.105 & 2.042 & 0.042 \\
\hline
\end{tabular}

TOT (total effect $=$ direct effect + indirect effect); DIR (direct effect); IND (indirect effect); The short form of the variables used in the PLS-SEM model are included here (for correspondence with the full names, please see right column in Table 1).

The "Perceived gravity of foreign land grabbing" did not have a significant effect directly on "Resistance to sell" ( $\beta=-0.007$, sig. $=0.906)$, but through "Perceived need for state intervention to limit foreign land grabbing" ( $\beta=0.419$, sig. $=0.000)$ and "Importance of buyer attributes" $(\beta=0.405$, sig. $=0.000)$, it was able to have a significant and positive effect on resistance to selling. Therefore, "Perceived gravity of foreign land grabbing" was able to influence resistance to sell in the presence of intermediaries such as "Perceived need for state intervention to limit foreign land grabbing" and "Importance of buyer attributes" $(\beta=0.092$, sig. $=0.069)$. As a result, the higher the "Perceived gravity of foreign land grabbing", the greater the "Resistance to sell". The "Perceived effect of foreign land grabbing on the natural environment" had a positive and significant effect on "Resistance to sell" $(\beta=0.141$, sig. $=0.006)$. This means that with increasing "Perceived effect of foreign land grabbing on the natural environment", "Resistance to sell" also increases. 
Moreover, the "Probability to join an association for farmers rights defense" had a positive and significant effect on "Resistance to sell". The indirect route through government intervention to "Resistance to sell" did not reveal a significant effect $(\beta=0.0 .012$, sig. $=0.181)$. Nevertheless, the total and direct effects were highly significant $(\beta=0.303$, sig. $=0.000)$. This result showed that with increasing "Probability to join an association for farmers rights defense", the tendency to "Resist to sell" increases.

"Perceived need for state intervention to limit foreign land grabbing" had a positive and significant effect on "Resistance to sell" $(\beta=0.105$, sig. $=0.042)$. It can be argued that with increasing the perceived need for government intervention, "Resistance to sell" also increases.

"Influence of price" had a significant negative effect on Resistance to sell" ( $\beta=-0.263$, sig. $=0.000)$. This means that by increasing the bid price to the owners, the owner is less likely to reject the purchase request when the price matters to him/her.

According to the structural model of the research, the values of Stone-Geisser's $Q^{2}$, $R^{2}$, and $R^{2}$ adj were investigated (Table 6). The results indicated that the value of $Q^{2}$ was positive for all endogenous variables and ranged from 0.119 to 0.285 , which revealed the ability to predict the model accurately [104]. $R^{2}$ values also indicated that the model has an acceptable level of predictive power $[101,105] . R^{2}$ adj showed that the constructs of the research model have the ability to explain $31.7 \%$ of the variance changes of the dependent variable of the model ("Resistance to sell"). $31.7 \%$ is an acceptable value to explain variance changes.

Table 6. The values of Stone-Geisser's $Q^{2}, R^{2}$, and $R^{2}$ adj.

\begin{tabular}{cccccc}
\hline Constructs & SSO & SSE & $\left.\mathbf{Q}^{\mathbf{2}} \mathbf{( = 1}-\mathbf{S S E} / \mathbf{S S O}\right)$ & $\mathbf{R}^{\mathbf{2}}$ & $\mathbf{R}^{\mathbf{2}} \mathbf{a d j .}$ \\
\hline Importance of buyer attributes & 996 & 877.785 & 0.119 & 0.3 & 0.295 \\
Resistance to sell & 332 & 237.494 & 0.285 & 0.332 & 0.317 \\
State intervention & 332 & 267.149 & 0.195 & 0.207 & 0.202 \\
\hline
\end{tabular}

\section{Discussion}

The study results revealed that the seven selected variables have a good capacity to explain landowners" "Resistance to sell" their land to foreign buyers. The fact the "Perceived gravity of foreign land grabbing over the next 10 years" and the "Perceived need for state intervention to limit foreign land grabbing" (Table 5) obtained the highest scores among the tested variables showed that the Romanian landowners believed that the phenomenon of land grabbing would seriously intensify in the next 10 years and that the government had a very high responsibility in limiting land grabbing. Interestingly, the results of PLS-SEM analysis indicated that the "Perceived gravity of foreign land grabbing over the next 10 years" did not have a direct effect on landowners' "Resistance to sell" their land ( $p=0.896$; Figure 3$)$.

In other words, it is not enough to raise awareness on the gravity of land grabbing among landowners to determine them not to sell their land to limit foreign land grabbing. This may be caused by the fact that landowners did not consider that their contribution through "Resistance to sell" their land could significantly impact the reduction of land grabbing gravity over a time-span of 10 years. However, "Perceived gravity of foreign land grabbing" had an indirect effect on "Resistance to Sell", through "Perceived need for state intervention to limit foreign land grabbing" and the "Importance of buyer attributes", which were both significant at $\mathrm{p}$-value 0.000 . This means that the more serious the perceived effect of land grabbing was, the higher landowners' resistance to sell their land was but only when they saw a high need for state intervention to limit land grabbing and when buyer attributes were important to them. In other words, in the absence of the "Perceived need for state intervention to limit foreign land grabbing", the perception of "Perceived gravity of foreign land grabbing" did not influence landowners" "Resistance to sell". This result can be attributed to the fact that people decide to support land grabbing limitation by resisting selling only when they consider that state intervention is required. The 
mediation effect of "Perceived need for state intervention to limit foreign land grabbing" could indicate that, for interviewed landowners, the necessity of state intervention reflects the gravity of land grabbing. It can also show landowners' trust in state capacity to limit land grabbing, which is not sustained in some cases because the state, through its legal framework and institutions, is acknowledged to be a significant driving factor for foreign land grabbing [106]. As land grabbing produces changes in how, for example, the needs of a local community are addressed, how resources are exploited, or how the employment contracts are executed [107], under some circumstances, paternalist policies (where "paternalism" means any intervention of governments or other authorities in private decision-making [108]) can be justifiable where high stakes are involved. Thus, the public authorities' dilemma will be to find a rationale for a restrictive approach to the existing fragmented public intervention on large-scale land transactions, which will probably displease many foreign investors and domestic landowners alike.

The "Importance of buyer attributes" also had predictive power on the dependent variable. It was observed that people who cared who were those to whom they could sell their land would be more reluctant in selling it to foreigners. Real-life situations lived by interviewed people or their friends and relatives and cases debated mainly through mass media have induced the fear that land was bought to a dangerous extent by foreign persons and companies [71]. This may be a factor that increased landowners' attention to buyer characteristics and determined them to consider attributes such as nationality or future land destination in land transactions. This result suggests that a simple action such as disclosing more about the potential buyer (such as nationality and future land destination given by the buyer) may determine landowners interested in buyer characteristics not to sell their land. Additionally, the "Importance of buyer attributes" mediated the relationship between the "Importance of the land price offered by the potential foreign buyer" and the "Resistance to sell".

The variable "Probability to join an association for farmers rights defense" had predictive power on landowners' "Resistance to sell" their land. Additionally, this variable indirectly affects the "Perceived need for state intervention to limit foreign land grabbing". Rawls [109] states simply that cooperation allows "a better life for all than any would have if each were to live solely by his own efforts". Thus, the ethical canon of "inclusiveness" (the principle of equitability) is applicable in this context and contributes to the foundation of the "good life" [80].

The Universal Declaration of Human Rights [110] proclaims the freedom of association as a fundamental right. This right enables non-state actors' participation in economic and social policy, and the implementation of this right is a critical element of every country's rule of law system. Article 12 of the EU Charter of Fundamental Rights enshrines this right, too. Any farmers' association offers them an excellent environment to promote their rights and interests, enhance their skills, and improve their livelihood. Romanian Ministry of Agriculture and Rural Development [111] acknowledges that the difficulty for small farmers to reach the market or obtain reliable information about the market can be overcome if they understand the benefits and agree to enter into farmers' associative forms. In Romania, only one percentage (1\%) of farmers are part of an associative structure, which contrasts sharply with other European Union member states [112]. In comparison, it should be noted that the European average is 34\% [112].

Romanian farmers are reluctant to join an association probably because of their experience during the communist period when their land was brutally taken away and they were forced to join the agricultural production cooperatives. The high prediction power of the "Probability to join an association for farmers rights defense" conveys the idea that the best way (among the ones tested in this study) to increase landowners' determination to refuse to sell their land to foreign investors is to offer them the possibility to join a farmers' association. The challenge is to create associations that farmers will trust and join. This causal relationship may be supported by the fact that the membership gives them the feeling that their rights are better protected, and they can resist possible pressure to sell; 
moreover, belonging to a community with similar ideas and behaviors may strengthen their choice not to sell. Thus, joining an association can, thus, reduce power asymmetry, which shapes the actual process of land grabbing, and it tends to give landowners the appearance of passive recipients [113]. Practically, as Fafchamps [114] puts it, one function that ethics can play in large-scale land acquisitions is that it can mediate conflictual relationships between asymmetric players and guide on what behaviors are acceptable and fair.

The path coefficient between "Perceived effect of foreign land grabbing on the natural environment" and "Perceived gravity of foreign land grabbing" is positive and significant. The highest the agreement that foreign land grabbing had negative consequences on the natural environment was, the strongest the "Resistance to sell" was, demonstrating that people cared about the state of the environment and that they considered themselves willing to accept a potential monetary loss from refusing to sell the land to protect the environment. Even if there is a well-known attitude-behavior gap [115], the fact that environmental damage of land grabbing has a significant effect on people's "Resistance to sell" is a good premise for strengthening this belief in the view of consolidating their decision to preserve ownership of their land.

The path coefficient between the "Perceived effect of agricultural land conversion to urban land" on "Resistance to sell" was positive and significant. The stronger the disagreement that the conversion of the agricultural land to urban was beneficial was, the higher landowners' resistance to sell their land was. Therefore, explaining to people the effects of this conversion and raising awareness of its negative consequences is a way to stimulate them not to sell. It is acknowledged that one of the main determinants of global change with visible consequences on human vulnerability and ecosystems is land-use change [116,117]. Urbanization-related land-use changes intensify competition between different land uses and threatens environmental sustainability and food security [118]. It influences rural people's livelihoods, and the loss of cropland can endanger a country's food security when agricultural production is mainly obtained through subsistence farming [28]. Thus, it can be inferred that land conversion to urban land through large-scale land acquisitions infringes the principle of moral economy that says that all individuals should get access to the resources necessary for their subsistence [119].

The lower the "Importance of the land price offered by the potential foreign buyer" was, the stronger the "Resistance to sell" was. This result can be attributed to the fact that protecting the land from being bought by foreigners is more critical for some landowners than the money they can earn by selling it, even if the amount offered is extensive. Another possibility stems from the land property situation in Romania. Land restitution in Romania after the fall of communism led to a highly fragmented private property, with over $90 \%$ of the total numbers of farms in Romania small farms of less than 0.5 ha (although they account only for less than $30 \%$ of the utilized agricultural area in Romania) [1]. The large share of small land plots and a low market price for land in Romania may determine landowners to think that their land does not value much. Thus, not selling the land to foreigners may worth more in their minds than the small amount of money they could gain from the land transaction. This finding illustrates that markets do not always function classically, and prices can sometimes be significantly different from the fundamentals of supply and demand would suggest [120]. Without getting into a debate about the just price, more should be investigated related to it within land transactions because, the just price, as a theory of ethics in economics, attempts to set standards of fairness in transactions.

\section{Conclusions}

The present study has revealed that land is a particular asset that must not be judged only as a mere commodity because it encompasses diverse functions, such as cultural, social, and environmental, that are difficult or impossible to embed correctly in a market value. This is one of the main reasons why land grabbing is a phenomenon with complex causes and effects, often challenging to understand and foreseen, especially by the local 
people whose perceptions can be easily biased by investors' promises to offer jobs, develop the infrastructure, and bring wellbeing to local people.

Given their role in land transactions, landowners should be knowledgeable in this respect and capable of making informed decisions regarding the consequences of selling their land. Objective and correct information-education campaigns, open discussions within community and between communities, creation of farmers' associations are several possibilities to open the way toward access to information.

Practically, this study extends the scant information on what factors determine landowners not to sell their land to foreigners to limit land grabbing. It showed that strengthening the determinants of joining a farmers' association, raising awareness on the importance of buyer attributes, increasing people perception of the negative effect of agricultural land conversion to urban land, of the negative effect of land grabbing on the environment, decreasing the relative importance of price received for land, and strengthening the image of the state as a necessary actor to limit land grabbing will increase landowners resistance to sell their land to foreigners.

Summing up, ethics in land transactions should embed the "moral imagination" that represents the creation of alternative options that imply consultations and negotiations able to reframe land grabbing dilemmas and create economically viable and morally justifiable solutions [121]. However, ethics is not a matter of negotiation. Things should not be considered black and white but as a matter of sound judgment and willingness to talk with other people involved [122]. The results of the present analysis testify how several factors that predict landowners' "Resistance to sell" their land to foreign investors, even if they offer an attractive price to limit the land grabbing phenomenon, can reveal ways of transforming the landowners into active actors within the efforts of reducing land grabbing. This does not mean under any circumstances that the landowners are the only stakeholders who should bear the responsibility to limit land grabbing. It means that they are active participants in these transactions and, consequently, their role must not be ignored, and they should responsibly play their part. Land grabbing is a complex phenomenon that needs to be addressed from many perspectives and by many actors that would ultimately lead to a real alternative to this type of investment [106]. Beyond the ethical concerns mentioned here and the role of landowners, further steps are needed to address better foreign large-scale land transactions, both their positive and negative outcomes.

The authors of this study acknowledge the existence of several limitations. A larger representative sample should generate more reliable information on landowners' resistance to sell their land at the country level. Another is that more variables should be added to the model to increase its prediction power, such as individual health, land quality, and family labor. Future research should focus on extending the understanding of land grabbing gravity perception by finding out what factors or phenomena make people consider land grabbing more or less severe. It is also worthy of investigating the mechanisms that might link the Corporate Social Responsibility strategies of big land investors and poverty alleviation in host countries. Further attention should be paid to the values of public institutions that are involved in land transactions. Authors acknowledge that statistical tests have a limited power to predict reality, especially in the context of the study of human behavior, which is very complex and difficult to be encoded in variables and statistical models. In this context, it would be useful to dedicate efforts to using additional methods to predict landowners' resistance to sell their land and compare results. Thus, less sophisticated statistical tests (e.g., regression) could be run; other option can be to carry on simulations in the social science lab by involving landowners in various scenarios that simulate possible land transactions and use different values of the variables (e.g., several price levels, and different buyer attributes) to observe how landowners react in each context. Despite its limitations, this study has the potential to guide decision-makers in their efforts to stimulate landowners to preserve land ownerships in front of foreign buying offers when ethical aspects of transactions, which are relevant to landowners, are infringed. 
Author Contributions: Conceptualization, R.M.P.-M. and D.C.P.; methodology, D.C.P. and H.R.K.; formal analysis, H.R.K.; writing-original draft preparation, R.M.P.-M. and D.C.P.; writing-review and editing, R.M.P.-M. and H.R.K.; funding acquisition, R.M.P.-M. All authors have equally contributed to this paper and are considered first author. All authors have read and agreed to the published version of the manuscript.

Funding: The APC was partially funded by Babes-Bolyai University: Seed grant no. 736/16.11.2020, UBB 2020 Development Fund.

Institutional Review Board Statement: Not applicable.

Informed Consent Statement: Informed consent was obtained from all subjects involved in the study.

Data Availability Statement: The data presented in this study are available on request from the corresponding author.

Conflicts of Interest: The authors declare no conflict of interest.

\section{References}

1. Burja, V.; Tamas-Szora, A.; Dobra, I.B. Land Concentration, Land Grabbing and Sustainable Development of Agriculture in Romania. Sustainability 2020, 12, 2137. [CrossRef]

2. Kay, S.; Peuch, J.; Franco, J. Extent of Farmland Grabbing in the EU. 2015. Available online: https:/ / www.europarl.europa.eu/ RegData/etudes/STUD/2015/540369/IPOL_STU(2015)540369_EN.pdf (accessed on 20 January 2021).

3. Giovannetti, G.; Ticci, E. Determinants of Biofuel-Oriented Land Acquisitions in Sub-Saharan Africa. Renew. Sustain. Energy Rev. 2016, 54, 678-687. [CrossRef]

4. Achiba, G.A. Navigating Contested Winds: Development Visions and Anti-Politics of Wind Energy in Northern Kenya. Land 2019, 8, 7. [CrossRef]

5. Benjaminsen, T.A.; Bryceson, I. Conservation, Green/Blue Grabbing and Accumulation by Dispossession in Tanzania. J. Peasant Stud. 2012, 39, 335-355. [CrossRef]

6. Ojeda, D. Green Pretexts: Ecotourism, Neoliberal Conservation and Land Grabbing in Tayrona National Natural Park, Colombia. J. Peasant Stud. 2012, 39, 357-375. [CrossRef]

7. Ryser, S. The Anti-Politics Machine of Green Energy Development: The Moroccan Solar Project in Ouarzazate and Its Impact on Gendered Local Communities. Land 2019, 8, 100. [CrossRef]

8. Cochrane, L. Food Security or Food Sovereignty: The Case of Land Grabs. J. Humanit. Assist. 2011, 5. Available online: https:/ / www.researchgate.net/profile/Logan-Cochrane/publication/291166891_Food_Security_or_Food_Sovereignty_The_ Case_of_Land_Grabs/links/569ed16608ae21a56424ef61/Food-Security-or-Food-Sovereignty-The-Case-of-Land-Grabs.pdf (accessed on 15 February 2021).

9. Petrescu-Mag, R.M.; Petrescu, D.C.; Reti, K.-O. My Land Is My Food: Exploring Social Function of Large Land Deals Using Food Security-Land Deals Relation in Five Eastern European Countries. Land Use Policy 2019, 82, 729-741. [CrossRef]

10. Lavers, T. 'Land Grab'as Development Strategy? The Political Economy of Agricultural Investment in Ethiopia. J. Peasant Stud. 2012, 39, 105-132. [CrossRef]

11. Teklemariam, D.; Nyssen, J.; Azadi, H.; Haile, M.; Lanckriet, S.; Taheri, F.; Witlox, F. Commercial Land Deals and the Interactions between Investors and Local People: Evidence from Western Ethiopia. Land Use Policy 2017, 63, 312-323. [CrossRef]

12. Tellman, B.; Magliocca, N.R.; Turner, B.; Verburg, P.H. Understanding the Role of Illicit Transactions in Land-Change Dynamics. Nat. Sustain. 2020, 3, 175-181. [CrossRef]

13. Constantin, C.; Luminița, C.; Vasile, A.J. Land Grabbing: A Review of Extent and Possible Consequences in Romania. Land Use Policy 2017, 62, 143-150. [CrossRef]

14. Petrescu-Mag, R.M.; Petrescu, D.C.; Petrescu-Mag, I.V. Whereto Land Fragmentation-Land Grabbing in Romania? The Place of Negotiation in Reaching Win-Win Community-Based Solutions. Land Use Policy 2017, 64, 174-185. [CrossRef]

15. EUROSTAT Agricultural Land Prices and Rents. Land Prices Vary Considerably between and within Member States. 2018. Available online: https: / / ec.europa.eu/eurostat/documents/2995521/8756523/5-21032018-AP-EN.pdf/b1d0ffd3-f75b-40ccb53f-f22f68d541df (accessed on 15 January 2021).

16. Cotula, L. Addressing the Human Rights Impacts of Land Grabbing. Brussels: Policy Department DG External Policies, European Parliament. 2014. Available online: https://www.europarl.europa.eu/RegData/etudes/STUD/2014/534984/EXPO_STU(20 14)534984_EN.pdf (accessed on 2 December 2020).

17. Baker-Smith, K.; Szocs Boruss, M.A. What Is Land Grabbing? A Critical Review of Existing Definitions; Eco Ruralis: Cluj Napoca, Romania, 2016; pp. 1-16. Available online: http://www.fao.org/family-farming/detail/en/c/1010775/ (accessed on 2 December 2020).

18. Hall, R. Land Grabbing in Southern Africa: The Many Faces of the Investor Rush. Rev. Afr. Political Econ. 2011, 38, 193-214. [CrossRef] 
19. Suhardiman, D.; Giordano, M.; Keovilignavong, O.; Sotoukee, T. Revealing the Hidden Effects of Land Grabbing through Better Understanding of Farmers' Strategies in Dealing with Land Loss. Land Use Policy 2015, 49, 195-202. [CrossRef]

20. Margulis, M.E.; McKeon, N.; Borras, S.M., Jr. Land Grabbing and Global Governance: Critical Perspectives. Globalizations 2013, 10, 1-23. [CrossRef]

21. Land Matrix Deals. 2021. Available online: https://landmatrix.org/list/deals (accessed on 10 March 2021).

22. Borras, S.M., Jr.; Franco, J.C. Global Land Grabbing and Trajectories of Agrarian Change: A Preliminary Analysis. J. Agrar. Chang. 2012, 12, 34-59. [CrossRef]

23. Hall, R.; Edelman, M.; Borras, S.M., Jr.; Scoones, I.; White, B.; Wolford, W. Resistance, Acquiescence or Incorporation? An Introduction to Land Grabbing and Political Reactions 'from Below'. J. Peasant Stud. 2015, 42, 467-488. [CrossRef]

24. Damen, M. Four EU Scenarios for Governance in a Post COVID-19 World. Lessons from Natural Resources Management. 2020. Available online: https:/ / www.europarl.europa.eu/RegData/etudes/STUD/2020/639317/EXPO_STU(2020)639317_EN.pdf (accessed on 15 February 2021).

25. Petrescu, D.C.; Hartel, T.; Petrescu-Mag, R.M. Global Land Grab: Toward a Country Typology for Future Land Negotiations. Land Use Policy 2020, 99, 104960. [CrossRef]

26. Cochrane, L.; Scholar, V. Land Grabbing. In Encyclopedia of Food and Agricultural Ethics; Springer: Berlin/Heidelberg, Germany, 2016; pp. 1-5. ISBN 978-94-007-0928-7.

27. Holmes, G. What Is a Land Grab? Exploring Green Grabs, Conservation, and Private Protected Areas in Southern Chile. J. Peasant Stud. 2014, 41, 547-567. [CrossRef]

28. Davis, K.F.; D’Odorico, P.; Rulli, M.C. Land Grabbing: A Preliminary Quantification of Economic Impacts on Rural Livelihoods. Popul. Environ. 2014, 36, 180-192. [CrossRef]

29. Margulis, M.E. Land Acquisitions for Food and Fuel. Encycl. Food Agric. Ethics 2014, 1325-1332.

30. Petrescu-Mag, R.M.; Petrescu, D.C.; Ozunu, A. Scientist, Quo Vadis Without Ethics? An Introduction to Special Collection on "Environmental Ethics: Issues and Perspectives from Romania". J. Agric. Environ. Ethics 2019, 32, 1-4. [CrossRef]

31. Meijboom, F.L.; Brom, F.W. Ethics and Sustainability: Guest or Guide? On Sustainability as a Moral Ideal. J. Agric. Environ. Ethics 2012, 25, 117-121. [CrossRef]

32. Bunkus, R.; Theesfeld, I. Land Grabbing in Europe? Socio-Cultural Externalities of Large-Scale Land Acquisitions in East Germany. Land 2018, 7, 98. [CrossRef]

33. Hausermann, H.; Ferring, D.; Atosona, B.; Mentz, G.; Amankwah, R.; Chang, A.; Hartfield, K.; Effah, E.; Asuamah, G.Y.; Mansell, C. Land-Grabbing, Land-Use Transformation and Social Differentiation: Deconstructing "Small-Scale" in Ghana's Recent Gold Rush. World Dev. 2018, 108, 103-114. [CrossRef]

34. Van der Ploeg, J.D.; Franco, J.C.; Borras, S.M., Jr. Land concentration and land grabbing in Europe: A preliminary analysis. Can. J. Dev. Stud./Rev. Can. Études Dév. 2015, 36, 147-162. [CrossRef]

35. Borras, S.M., Jr.; Franco, J.C. Global Land Grabbing and Political Reactions 'from Below'. Third World Q. 2013, 34, 1723-1747. [CrossRef]

36. Margulis, M.E.; Porter, T. Governing the Global Land Grab: Multipolarity, Ideas, and Complexity in Transnational Governance. Globalizations 2013, 10, 65-86. [CrossRef]

37. Van Duy, L.; Amekawa, Y.; Isoda, H.; Nomura, H.; Watanabe, T. Are Socialist Domestic Land Grabs Egalitarian? Insights from a Case Involving a Rubber Plantation in Dien Bien Province, Vietnam. Geoforum 2020, 114, 89-106. [CrossRef]

38. Zoomers, A. Globalisation and the Foreignisation of Space: Seven Processes Driving the Current Global Land Grab. J. Peasant Stud. 2010, 37, 429-447. [CrossRef]

39. Pyle, L.A. Persistent Landownership at the Rural-Urban Fringe. Urban Geogr. 1989, 10, 157-171. [CrossRef]

40. Grubbström, A. Emotional Bonds as Obstacles to Land Sale-Attitudes to Land among Local and Absentee Landowners in Northwest Estonia. Landsc. Urban Plan. 2011, 99, 31-39. [CrossRef]

41. Grubbström, A.; Eriksson, C. Retired Farmers and New Land Users: How Relations to Land and People Influence Farmers' Land Transfer Decisions. Sociol. Rural. 2018, 58, 707-725. [CrossRef]

42. Lai, P.-H.; Kreuter, U.P. Examining the Direct and Indirect Effects of Environmental Change and Place Attachment on Land Management Decisions in the Hill Country of Texas, USA. Landsc. Urban Plan. 2012, 104, 320-328. [CrossRef]

43. Asiama, K.O.; Bennett, R.; Zevenbergen, J.; Asiama, S.O. Land Valuation in Support of Responsible Land Consolidation on Ghana's Rural Customary Lands. Surv. Rev. 2018, 50, 288-300. [CrossRef]

44. Mazzucato, M. Capitalism's Greatest Weakness? It Confuses Price with Value. World Economic Forum. 2018. Available online: https:/ /www.weforum.org/agenda/2018/05/capitalisms-greatest-weakness-it-confuses-price-with-value/ (accessed on 10 January 2021).

45. Lefebvre, H.; Nicholson-Smith, D. The Production of Space; Blackwell: Oxford, UK, 1991; Volume 142.

46. Harvey, D. The Enigma of Capital and the Crises of Capitalism Profile Books; Profile Books: London, UK, 2010 ; ISBN 1846683092.

47. Polanyi, K. Great Transformation; Beacon Press: Boston, MA, USA, 2002.

48. Farrell, H. The Free Market Is an Impossible Utopia. The Washington Post, 18 July 2014; Retrieved 25 August 2015.

49. Bollier, D. Why Karl Polanyi Still Matters? On The Commons, 24 February 2009.

50. De Maria, M. Understanding Land in the Context of Large-Scale Land Acquisitions: A Brief History of Land in Economics. Land 2019, 8, 15. [CrossRef] 
51. Barry, A. Ethical capitalism. In Global Governmentality: Governing International Spaces; Routledge: New York, NY, USA, 2006; Volume 28, pp. 195-211. ISBN 1-134-38609-5.

52. Langstaff, D.H. Ethical Capitalism-Who Should Care? 2014. Available online: https://www.aspeninstitute.org/wp-content/ uploads/files/content/upload/Ethical\%20Capitalism-GATech-DHL\%20FINAL-Feb192014.pdf (accessed on 7 January 2021).

53. Bisanz, P. How to Make Capitalism More Ethical. World Economic Forum. 2014. Available online: https://www.weforum.org/ agenda/2014/11/how-to-make-capitalism-more-ethical/ (accessed on 7 January 2021).

54. Cvetkovich, G.; Earle, T.C. Environmental Hazards and the Public. J. Soc. Issues 1992, 48, 1-20. [CrossRef]

55. Borras, S., Jr.; Franco, J. From Threat to Opportunity-Problems with the Idea of a Code of Conduct for Land-Grabbing. Yale Hum. Rts. Dev. $L j$ 2010, 13, 507.

56. Siciliano, G. Rural-urban Migration and Domestic Land Grabbing in China. Popul. Space Place 2014, 20, 333-351. [CrossRef]

57. Zoomers, A.; Van Noorloos, F.; Otsuki, K.; Steel, G.; Van Westen, G. The Rush for Land in an Urbanizing World: From Land Grabbing toward Developing Safe, Resilient, and Sustainable Cities and Landscapes. World Dev. 2017, 92, 242-252. [CrossRef]

58. Cox, E.M.; Pidgeon, N.; Spence, E.; Thomas, G. Blurred Lines: The Ethics and Policy of Greenhouse Gas Removal at Scale. Front. Environ. Sci. 2018, 6, 38. [CrossRef]

59. Dell'Angelo, J.; Rulli, M.C.; D'Odorico, P. The Global Water Grabbing Syndrome. Ecol. Econ. 2018, 143, 276-285. [CrossRef]

60. Neef, A.; Touch, S.; Chiengthong, J. The Politics and Ethics of Land Concessions in Rural Cambodia. J. Agric. Environ. Ethics 2013, 26, 1085-1103. [CrossRef]

61. Holt Giménez, E.; Shattuck, A. Food Crises, Food Regimes and Food Movements: Rumblings of Reform or Tides of Transformation? J. Peasant Stud. 2011, 38, 109-144. [CrossRef] [PubMed]

62. Rowden, R. Indian Companies Engaged in Agricultural "Land Grabbing" in Africa: The Need for Indo-African Solidarity Linkages. Hum. Geogr. 2011, 4, 72-87. [CrossRef]

63. Nara, B.B.; Lengoiboni, M.; Zevenbergen, J. Implications of Customary Land Rights Inequalities for Food Security: A Study of Smallholder Farmers in Northwest Ghana. Land 2020, 9, 178. [CrossRef]

64. Toft, K.H. Are Land Deals Unethical? The Ethics of Large-Scale Land Acquisitions in Developing Countries. J. Agric. Environ. Ethics 2013, 26, 1181-1198. [CrossRef]

65. Busscher, N.; Vanclay, F.; Parra, C. Reflections on How State-Civil Society Collaborations Play out in the Context of Land Grabbing in Argentina. Land 2019, 8, 116. [CrossRef]

66. Zevenbergen, J.; Augustinus, C.; Antonio, D.; Bennett, R. Pro-Poor Land Administration: Principles for Recording the Land Rights of the Underrepresented. Land Use Policy 2013, 31, 595-604. [CrossRef]

67. Cotula, L. The International Political Economy of the Global Land Rush: A Critical Appraisal of Trends, Scale, Geography and Drivers. J. Peasant Stud. 2012, 39, 649-680. [CrossRef]

68. Deininger, K.; Byerlee, D. Rising Global Interest in Farmland: Can It Yield Sustainable and Equitable Benefits? World Bank Publications: Washington, DC, USA, 2011; ISBN 0-8213-8592-5.

69. Edelman, M.; León, A. Cycles of Land Grabbing in Central America: An Argument for History and a Case Study in the Bajo Aguán, Honduras. Third World Q. 2013, 34, 1697-1722. [CrossRef]

70. Fairbairn, M. Foreignization, Financialization and Land Grab Regulation. J. Agrar. Chang. 2015, 15, 581-591. [CrossRef]

71. Petrescu-Mag, R.M.; Petrescu, D.C.; Todoran, S.C.; Petrescu-Mag, I.V. Us and Them. Is the COVID-19 Pandemic a Driver for Xenophobia in Land Transactions in Romania? Land Use Policy 2021, 103, 105284. [CrossRef]

72. Cuffaro, N.; Hallam, D. 'Land Grabbing'in Developing Countries: Foreign Investors, Regulation and Codes of Conduct. Regul. Codes Conduct. 2011, 3, 1-18.

73. Corbera, E.; Hunsberger, C.; Vaddhanaphuti, C. Climate Change Policies, Land Grabbing and Conflict: Perspectives from Southeast Asia. Can. J. Dev. Stud. 2017, 38, 297-304. [CrossRef]

74. German, L.; Schoneveld, G.; Mwangi, E. Contemporary Processes of Large-Scale Land Acquisition in Sub-Saharan Africa: Legal Deficiency or Elite Capture of the Rule of Law? World Dev. 2013, 48, 1-18. [CrossRef]

75. Petrescu, D.C.; Petrescu-Mag, R.M.; Tenter, A.R. The Little Chernobyl of Romania: The Legacy of a Uranium Mine as Negotiation Platform for Sustainable Development and the Role of New Ethics. J. Agric. Environ. Ethics 2019, 32, 51-75. [CrossRef]

76. Barnett, C.; Cloke, P.; Clarke, N.; Malpass, A. Consuming Ethics: Articulating the Subjects and Spaces of Ethical Consumption. Antipode 2005, 37, 23-45. [CrossRef]

77. Petrescu-Mag, R.M.; Petrescu, D.C.; Robinson, G.M. Adopting Temperance-Oriented Behavior? New Possibilities for Consumers and Their Food Waste. J. Agric. Environ. Ethics 2019, 32, 5-26. [CrossRef]

78. Resnik, D. What Is Ethics in Research \& Why Is It Important? Available online: https:/ /www.niehs.nih.gov/research/resources/ bioethics/whatis/index.cfm (accessed on 27 December 2020).

79. Donohoe, M. Causes and Health Consequences of Environmental Degradation and Social Injustice. Soc. Sci. Med. 2003, 56, 573-587. [CrossRef]

80. Bawden, R. How Should We Farm? The Ethical Dimension of Farming Systems. In Farming Systems Research into the 21st Century: The New Dynamic; Springer: Berlin/Heidelberg, Germany, 2012; pp. 119-139.

81. Liao, C.; Jung, S.; Brown, D.G.; Agrawal, A. Spatial Patterns of Large-scale Land Transactions and Their Potential Socioenvironmental Outcomes in Cambodia, Ethiopia, Liberia, and Peru. Land Degrad. Dev. 2020, 31, 1241-1251. [CrossRef] 
82. Davis, K.F.; Yu, K.; Rulli, M.C.; Pichdara, L.; D'Odorico, P. Accelerated Deforestation Driven by Large-Scale Land Acquisitions in Cambodia. Nat. Geosci. 2015, 8, 772-775. [CrossRef]

83. Schoneveld, G.C. Host Country Governance and the African Land Rush: 7 Reasons Why Large-Scale Farmland Investments Fail to Contribute to Sustainable Development. Geoforum 2017, 83, 119-132. [CrossRef]

84. Krishna, V.V.; Kubitza, C.; Pascual, U.; Qaim, M. Land Markets, Property Rights, and Deforestation: Insights from Indonesia. World Dev. 2017, 99, 335-349. [CrossRef]

85. Cardoso, S.P.; James, H.S., Jr. Ethical Frameworks and Farmer Participation in Controversial Farming Practices. J. Agric. Environ. Ethics 2012, 25, 377-404. [CrossRef]

86. Ferrell, O.C.; Gresham, L.G. A Contingency Framework for Understanding Ethical Decision Making in Marketing. J. Mark. 1985, 49, 87-96. [CrossRef]

87. Jones, T.M. Ethical Decision Making by Individuals in Organizations: An Issue-Contingent Model. Acad. Manag. Rev. 1991, 16, 366-395. [CrossRef]

88. Meijboom, F.L.; Stafleu, F.R. Farming Ethics in Practice: From Freedom to Professional Moral Autonomy for Farmers. Agric. Hum. Values 2016, 33, 403-414. [CrossRef]

89. Brugha, R.; Varvasovszky, Z. Stakeholder Analysis: A Review. Health Policy Plan. 2000, 15, 239-246. [CrossRef]

90. Presidential Administration of Romania. Romania. 2021. Available online: https://www.presidency.ro/ro/presedinte/romania (accessed on 10 January 2021).

91. Romanian Ministry of Agriculture and Rural Development. National Rural Development Programme for the 2014-2020 Period. Official Version 28/01/2021. Available online: https://www.madr.ro/docs/dezvoltare-rurala/2021/PNDR.2020_V12_26.01.2021 .pdf (accessed on 10 February 2021).

92. Statista. Romania: Share of Economic Sectors in the Gross Domestic Product (GDP) from 2009 to 2019. 2020. Available online: https:/ / www.statista.com/statistics/373136/share-of-economic-sectors-in-the-gdp-in-romania/\#: \{\}:text=This\%20 statistic\%20shows\%20the\%20share, sector\%20contributed\%20about\%2058.16\%20percent (accessed on 10 January 2021).

93. United Nations Development Programme. Human Development Report. 2020. Available online: http://hdr.undp.org/en/ content/latest-human-development-index-ranking (accessed on 7 January 2021).

94. James, H.S., Jr.; Hendrickson, M.K. Perceived Economic Pressures and Farmer Ethics. Agric. Econ. 2008, 38, 349-361. [CrossRef]

95. Stuart, D. Constrained Choice and Ethical Dilemmas in Land Management: Environmental Quality and Food Safety in California Agriculture. J. Agric. Environ. Ethics 2009, 22, 53. [CrossRef]

96. Vaske, J.J.; Miller, C.A.; Toombs, T.P.; Schweizer, L.A.; Powlen, K.A. Farmers' Value Orientations, Property Rights and Responsibilities, and Willingness to Adopt Leopold's Land Ethic. Soc. Nat. Resour. 2018, 31, 1118-1131. [CrossRef]

97. Messerli, P.; Heinimann, A.; Giger, M.; Breu, T.; Schönweger, O. From 'Land Grabbing'to Sustainable Investments in Land: Potential Contributions by Land Change Science. Curr. Opin. Environ. Sustain. 2013, 5, 528-534. [CrossRef]

98. Tripathi, A.; Mishra, A.K. Knowledge and Passive Adaptation to Climate Change: An Example from Indian Farmers. Clim. Risk Manag. 2017, 16, 195-207. [CrossRef]

99. Jha, S.; Kaechele, H.; Lana, M.; Amjath-Babu, T.; Sieber, S. Exploring Farmers' Perceptions of Agricultural Technologies: A Case Study from Tanzania. Sustainability 2020, 12, 998. [CrossRef]

100. Liu, H.; Luo, X. Understanding Farmers' Perceptions and Behaviors towards Farmland Quality Change in Northeast China: A Structural Equation Modeling Approach. Sustainability 2018, 10, 3345. [CrossRef]

101. Hair, J.F., Jr.; Hult, G.T.M.; Ringle, C.; Sarstedt, M. A Primer on Partial Least Squares Structural Equation Modeling (PLS-SEM); Sage Publications: Thousand Oaks, CA, USA, 2016; ISBN 1-4833-7743-1.

102. Zhu, X.; Zhang, P.; Wei, Y.; Li, Y.; Zhao, H. Measuring the Efficiency and Driving Factors of Urban Land Use Based on the DEA Method and the PLS-SEM Model-A Case Study of 35 Large and Medium-Sized Cities in China. Sustain. Cities Soc. 2019, 50, 101646. [CrossRef]

103. Garson, G.D. Partial Least Squares. Regression and Structural Equation Models; 2016 Edition; Statistical Associates Publishers: Asheboro, NC, USA, 2016; ISBN1 -10: 1626380392. ISBN2 -13: 978-1-62638-039-4.

104. Henseler, J.; Ringle, C.M.; Sinkovics, R.R. The Use of Partial Least Squares Path Modeling in International Marketing. In New Challenges to International Marketing; Emerald Group Publishing Limited: Bingley, UK, 2009; ISBN 1-84855-468-0.

105. Chin, W.W.; Newsted, P.R. Structural Equation Modeling Analysis with Small Samples Using Partial Least Squares. Stat. Strateg. Small Sample Res. 1999, 1, 307-341.

106. De Schutter, O. How Not to Think of Land-Grabbing: Three Critiques of Large-Scale Investments in Farmland. J. Peasant Stud. 2011, 38, 249-279. [CrossRef]

107. Bardy, R.; Drew, S.; Kennedy, T.F. Foreign Investment and Ethics: How to Contribute to Social Responsibility by Doing Business in Less-Developed Countries. J. Bus. Ethics 2012, 106, 267-282. [CrossRef]

108. Thomas, M.; Buckmaster, L. Paternalism in Social Policy: When Is It Justifiable? Research Paper no. 8 2010-11. 2010. Available online: https:/ / apo.org.au/sites/default/files/resource-files/2011-01/apo-nid23596.pd (accessed on 5 March 2021).

109. Rawls, J. A Theory of Justice, 2nd ed.; Harvard University Press: Cambridge, UK, 1999.

110. The United Nations Organization. Universal Declaration of Human Rights. 1948. Available online: https://www.un.org/en/ about-us / universal-declaration-of-human-rights (accessed on 9 November 2020). 
111. Romanian Ministry of Agriculture and Rural Development Strategy for the Development of the Agri-Food Sector on Medium and Long Term. Horizon 2020-2030. 2015. Available online: https://www.madr.ro/docs/agricultura/strategia-agroalimentara2020-2030.pdf (accessed on 10 January 2021).

112. Popescu, A. Cercetari cu privire la rolul asocierii si cooperarii in cresterea eficientei valorificarii produselor agroalimentare [Research on the Role of Association and Cooperation to Increase the Efficiency of Agri-Food Products]. Ph.D. Thesis, Banat University of Agricultural Sciences and Veterinary Medicine of Timisoara, Timisoara, Romania, 2017.

113. Budy, F.C. Political Reactions from below to Sime Darby Land Grab: Generational Shift, Geographical Reach, Rural Influencers and Multi-Stakeholder Alliance. J. Rural Stud. 2020, 17, 193-201. [CrossRef]

114. Fafchamps, M. Solidarity Networks in Preindustrial Societies: Rational Peasants with a Moral Economy. Econ. Dev. Cult. Chang. 1992, 41, 147-174. [CrossRef]

115. Vermeir, I.; Verbeke, W. Sustainable Food Consumption: Exploring the Consumer "Attitude-Behavioral Intention" Gap. J. Agric. Environ. Ethics 2006, 19, 169-194. [CrossRef]

116. Foley, J.A.; DeFries, R.; Asner, G.P.; Barford, C.; Bonan, G.; Carpenter, S.R.; Chapin, F.S.; Coe, M.T.; Daily, G.C.; Gibbs, H.K. Global Consequences of Land Use. Science 2005, 309, 570-574. [CrossRef]

117. Verburg, P.H.; Van De Steeg, J.; Veldkamp, A.; Willemen, L. From Land Cover Change to Land Function Dynamics: A Major Challenge to Improve Land Characterization. J. Environ. Manag. 2009, 90, 1327-1335. [CrossRef]

118. Chen, J. Rapid Urbanization in China: A Real Challenge to Soil Protection and Food Security. Catena 2007, 69, 1-15. [CrossRef]

119. Colin, J.-P. Securing Rural Land Transactions in Africa. An Ivorian Perspective. Land Use Policy 2013, 31, 430-440. [CrossRef]

120. Boyd, W. Just Price, Public Utility, and the Long History of Economic Regulation in America. Yale J. Reg. 2018, $35,721$.

121. Werhane, P.H. Moral Imagination. Wiley Encycl. Manag. 2015, 1-2. [CrossRef]

122. Solomon, R.C. It's Good Business: Ethics and Free Enterprise for the New Millenium; Rowman \& Littlefield: Maryland, MD, USA, 1997; ISBN 0-8476-8804-6. 